\title{
ISLAMIC IDENTITY VERSUS CITY/PLACE BRANDING
}

\author{
M. Alaa Mandour
}

Civil and Architecture Engineering Department

Sultan Qaboos University, Oman

e-mail: mandour@squ.edu.om

\begin{abstract}
Is a brand a product, a service, or a company? Is it a logo, a marketing strategy or an attitude? As globalization intensifies, places increasingly compete with other places for attention, influence, markets, investments, businesses, visitors, residents, talent and events. And competition is no longer restricted to the well-known places down the road, over the hill or across the water. Places now compete with cities, regions and countries halfway around the world. Places are increasingly getting caught off guard by unpredicted and apparently rapid shifts in competition and abruptly lose their historic purpose or their competitive edge, be it economic, social or cultural. Culture fills our cities, regions, nations and even our rural landscapes with spiritual content. Our places are an expression of who we are and what we value and they are ruthless in projecting the bad alongside the good. In its widest sense culture includes art, design, education, science, religion and sport. In the context of place branding it is the manifestation of our beliefs, values, customs and behaviors. Merging culture to brand within our city tissue is an essential part of the morphology within its spaces. This paper is trying to discuss the contribution of Islamic culture to a place brand; Relationship between culture and identity, image, visual identity etc. in the context of place branding; Impact of culture on brand equity; Developing cultural brand assets to brand places and how should we value and evaluate culture in the context of place branding? Also will try to find answers to the following: Do we have a precise understanding of how Islamic culture adds value to or devalues a place? Do we have a methodology for capturing the value of our Islamic culture to places? And, can this culture be developed with the intent to create better places and place brands?
\end{abstract}

Keywords: Place branding, morphology, marketing, Islamic culture, identity

\begin{abstract}
Abstrak
Apakah sebuah brand adalah sebuah produk, sebuah layanan, ataukah sebuah perusahaan? Apakah hal itu tentang logo, strategi pemasaran, ataukah tentang perilaku? Seiring dengan semakin masifnya globalisasi, setiap tempat semakin berkompetisi dengan tempat-tempat lainnya untuk meraih pengaruh, perhatian, pasar, investasi, bisnis, kunjungan, dan even-even. Persaingan tidak lagi terbatas pada tempat-tempat terkenal saja. Masing-masing tempat kini bersaing dengan kota-kota, daerah, dan negara-negara di belahan dunia. Tempat semakin terperangkap oleh perubahan cepat yang tidak diperkirakan dalam kompetisi dan tiba-tiba kehilangan tujuan bersejarah atau daya saing mereka, baik itu ekonomi, sosial, atau budaya. Budaya mengisi kota-kota kita, daerah, bangsa dan bahkan lansekap pedesaan kita dengan spiritualitas. Tempat kita adalah sebuah ekspresi dari siapa kita dan apa yang kita nilai dan mampu memproyeksikan buruk di samping yang baik. Dalam artian yang luas budaya meliputi seni, desain, pendidikan, ilmu pengetahuan, agama, dan olahraga. Dalam konteks branding tempat itu adalah manifestasi dari kami, nilai-nilai kepercayaan, kebiasaan dan perilaku. Penggabungan budaya untuk brand dalam jaringan kota kita adalah bagian penting dari morfologi dalam ruangruang tersebut. Tulisan ini mencoba untuk membahas kontribusi budaya Islam untuk brand sebuah tempat; hubungan antara budaya dan identitas, gambar, dan identitas visual dalam konteks branding tempat; dampak budaya pada ekuitas brand; Mengembangkan aset brand ke tempat-tempat budaya brand dan bagaimana kita harus menghargai dan mengevaluasi budaya dalam konteks branding tempat? Juga akan mencoba untuk menemukan jawaban sebagai berikut: Apakah kita memiliki pemahaman yang tepat tentang bagaimana budaya Islam menambah nilai atau merendahkan tempat? Apakah kita memiliki metodologi untuk menangkap nilai budaya Islam kita ke tempat? Dan, dapatkah budaya ini dikembangkan dengan maksud untuk menciptakan tempat yang lebih baik dan brand tempat?
\end{abstract}

Kata kunci: Morfologi, branding tempat, identitas, budaya Islam

\section{Introduction}

Cities, regions and countries all over the world are faced with the effects that economic and cultural globalization and other major trends pose to the environment that these places operate in, and are challenged by changes in their economic, cultural and social mosaic. One of these effects is increased competition among places, which is apparent in various levels and fields of activity ${ }^{1}$.

The application of marketing places stems from two distinct trends. The first is theoretical and has to do with the development of new marketing ap- 
proaches, specifically concerned with non-business or non-profit organizations ${ }^{2}$. Especially the notion of Image Marketing, which stems from the realization that images can be effectively marketed while the products to which they relate remain vaguely delineated $^{3}$, was warm-heartedly accepted by city administrators.

The second trend stems from the practice of city administrators, who found themselves in onset of an 'urban crisis', which was widely perceived as leading to the potential terminal decline of traditional urban economies, with a consequent imperative for economic restructuring and which "stimulated the search for new roles for cities and new ways of managing their problems" 4 .

\section{Trends of Place Branding}

Recently there is an apparent shift towards branding, which has been recognized widely in the literature $^{5}$ and is evident in the practice of place marketing. The popularity and success of product branding and mostly the advent of corporate branding and other corporate-level marketing concepts, which in reality frees the application of marketing from the dependence on the physical product, are the main generators of interest on place branding. In the literature, distinct trends of discussion have emerged $^{6}$, Figure $1 \& 2$.

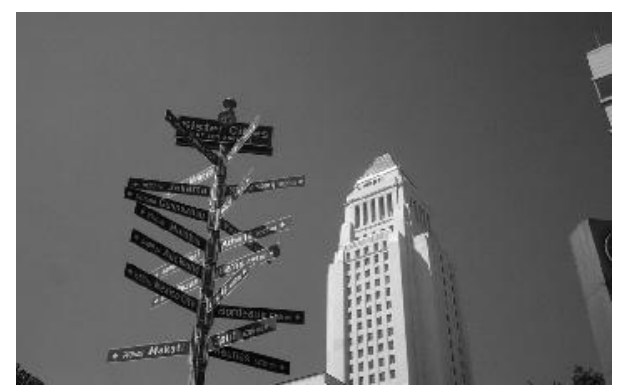

Figure 1. Signage in Los Angeles (Source: Bitterman, Alex: "Brand-topia Understanding Place Branding Through Context \& Precedent")

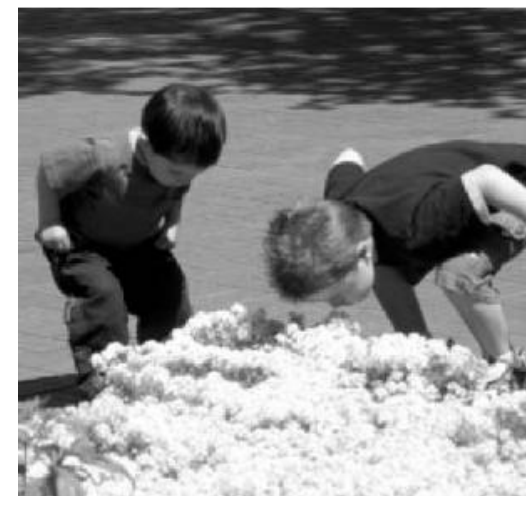

Figure 2. Pioneer Courthouse Square

(Source: Bitterman, Alex: "Brand-topia Understanding Place Branding Through Context \& Precedent")

\section{Place of Origin Branding}

This trend has developed within the market-ing discipline and has grown to a large body of publications. ${ }^{7}$ It concerns the usage of the place of origin in branding a product. Using the qualities, images and, in most cases, stereotypes of the place and the people living in that place to brand a product that is produced in that place is considered an effective strategy. In essence though, it has little to do with the concept of place branding.

\section{Nations Branding}

This trend has also developed within the marketing discipline and especially within the circles of marketing consultants, who act as advisors to national governments, that have realized the potential advantages of branding their country but do not have the knowledge and skills necessary to design and implement branding campaigns and strategies. $^{8}$ The interest lies usually in the positive effects of branding the nation for the benefit of tourism development and the attraction of foreign investment. The topic has grown considerably, so that some commentators propose that the whole foreign affairs policy of the country should be thought of as a branding exercise. A growing number of researchers are examining the potential and suitability of branding nations ${ }^{9}$ or specific methods and cases $^{10}$.

\section{Destination Branding}

Perhaps the most developed in theory and most used in practice trend within place branding has been the investigation of the role of branding in the marketing of tourism destinations. ${ }^{11}$ Starting, from the realization that destinations are visited because of their prior images, and they are consumed based on a first-hand comparison of those images with the reality faced in the destination itself, this trend has offered a lot in the theory of place branding. The largest part, at least of the theoretical development in this field comes from Hankinson ${ }^{12}$. Starting from his belief that "as yet no general theoretical framework exists to underpin the development of place brands apart from classical, product-based branding theory ${ }^{13}$, he provides a refined framework for understanding cities as brand. Brent Ritchie and Ritchie recognize that a destination brand has the potential to play a coordinating role "for a broad range of community development efforts", and stress the need for other agencies to align with branding the destination brand, in this way realizing that destination branding is only part of the whole branding effort of any place ${ }^{14}$. 


\section{Culture Branding}

Another interesting and steadily growing trend has been the examination of the effects of cultural branding on the physical, economic and (sometimes) social environment of cities. ${ }^{15}$ Widely applied in cities all over the world, this cultural branding owes its development to the growing importance of the cultural, leisure and entertainment industries within the contemporary economy, as much for tourists and other visitors, as for the local population. At the same time, attempts to incorporate this trend in planning the city ${ }^{16}$ and the increased importance of image-based industries and the people these employ ${ }^{17}$ is reinforcing the processes involved in this kind of place branding. Connected with this trend, one can identify a more recent discussion, especially among urban designers, on the effects of high-profile buildings on the city's image the use of such buildings and other 'landmarks' in general in the city's promotion ${ }^{18}$.

\section{Case Studies}

\section{The Ferrari Experience, Yas Island Abu Dhabi}

Yas Island (Figure 3), occupies a total land area of 2,500 hectares, of which 1,700 hectares will be claimed for development. The Island will feature attractions such as a world-class motor sports racetrack, signature hotels, the Ferrari theme park, Water Park, and the Abu Dhabi destination retail development of 300,000 sq m retail area, links and parkland golf courses, lagoon hotels, marinas, polo clubs, apartments, villas and numerous food \&beverage outlets that will create a unique international tourist destination.

The Ferrari Theme Park (Figure 4) is a part of Yas Island and it is planned with the notion of branded themed entertainment destination offering a range of 24 themed attractions. It includes a 70 metre-high $\mathrm{G}$ Force tower, a twin rollercoaster and a rally driving track. It also offers an 18-screen theatre complex and a multitude of food and beverage outlets.

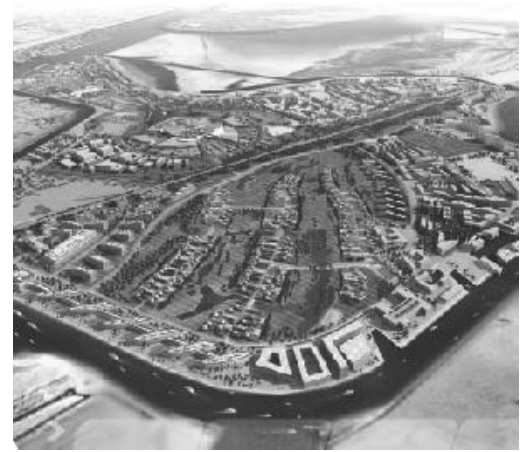

Figure 3. Yas Island Abu Dhabi (Source: http://www. skyscrapercity.com/showthread.php?t=281561)

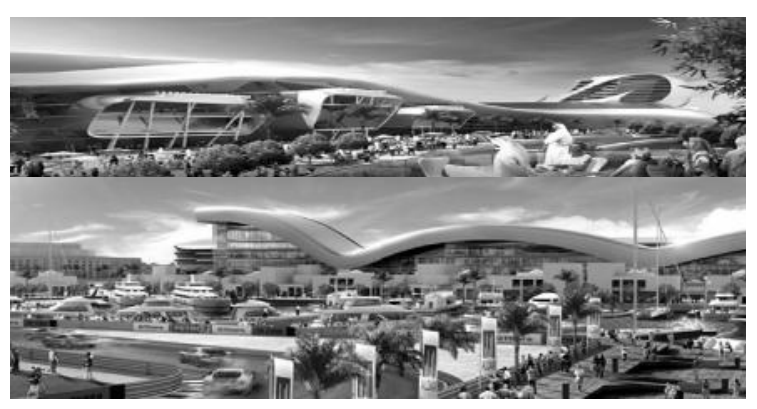

Figure 4. Ferrari Island

(Source: http://www.skyscrapercity.com/ showthread.php?t=281561)

It's no surprise then that in an increasingly competitive world places are recognizing that they need to distinguish themselves from their competition if they are to develop, retain and attract talent, investors, institutions, companies and tourists and successfully export their products, services, values and lifestyle. And in an increasingly bland world of global brands and packaged culture promoted through increasingly bland communications, places need to distinguish themselves in terms of their culture, their heritage, their environment, their economy - most particularly in terms of the knowledge, the creativity and the innovation of their people and enterprises and in the way they communicate about themselves.

\section{Analysis}

Applying the concept of brand to the project related to Islamic Cultural brand and practice few policy analysts and urban/place professionals have given it a great deal of thought and it has been true that, it tends to dismiss any concern with the image of Islamic culture places and cities as a superficial and transitory worry." ${ }^{19}$ However, there are counter views to this position. As has been argued by Simon Anholt in a recent Economist review of brands and branding ${ }^{20}$, "Places have always been brands..." and "the reputations of places have always been managed and occasionally invented by their leaders, who have often borrowed from others to augment their political skills: poets, orators, philosophers, film-makers, artists, writers." In his book "Brand New Justice" 21 Anholt demonstrates that a cultural brand is as important to places as it is to the provision of goods and services. But culture place branding is different from product branding and has a much bigger role to play. As Anholt says "A national brand strategy determines the most realistic, most competitive and most compelling strategic vision for the country, and ensures that this vision is supported, reinforced and enriched by every act of communication between the country and the rest of the world. Those acts of communication include the kinds of brands which the country 
exports; the way it promotes itself for trade, tourism, inward investment and inward recruitment; the way it behaves in acts of domestic and foreign policy and the ways in which these acts are communicated; the way its citizens behave when abroad and how they treat strangers at home, the way it features in the world's media; the bodies and organizations it belongs to; the countries it associates with; the way it competes with other countries in sport and entertainment; what it gives to the world and what it takes back." If done well, as Anholt says, "such a strategy can make a huge difference to both the internal confidence and the external performance of a country."

\section{Opera Dubai}

The emblematic city of the explosion of the $21^{\text {st }}$ century must build itself a new planetary icon (Figure 5). But an opera is an opera: An allusion to music, to rhythm... a reference to the rhythms of the past... an invitation to discovery... a mystery programmed. We are here above the water, at the far end of the Creek. The visitor encounters an "inhabitant" who belongs to the spirit of the time, belongs to the time inscribed in the place. It acts as a witness, a guardian, a protector and, above all else, a vision across the city and its future. Its scale is such that we can not confuse it with a vulgar hotel or an office building: it is proud, sure of its aura across the land. It cannot be decoded in a simplistic or univocal manner. Its image changes with angles of view, with the lights, but it also belongs to the atmosphere, to the thickness of the air. It reveals the light. It impregnates its shadow in the water. It evokes the rhythms, the intensities, and the depths. It evokes the music, the ascents, and the descents.
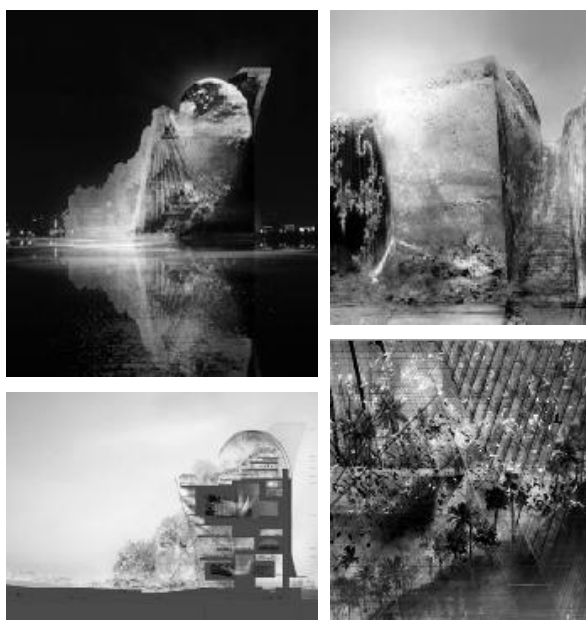

Figure 5. Dubai Opera

(Source: http://www.dezeen.com/2007/05/01/dubaiopera-by-jean-nouvel/

It speaks of the symbols of the place: here, we are as likely to encounter the bird (the falcon that is the emblem of the Emirates, that flies and migrates, searching for refuge in nature nearby); as the water (changing reflections linked to the mirrors of the Creek); as the waves of the sea so close; as the waterfall, the mist or the cloud. We also encounter vegetation with its perforated patterns of light, the random succession and superposition of palm trees entangled with other essences as the levels progress; as the music with its evocations of the curves of instruments, of the lines the score, of the keys of the clarinet or of the tuning note. The signs superpose, become confused, link together to create other music, other rhythms impossible to imagine outside of these crisscrossed layers. It is a little like the clouds: each person can see what attracts them, what makes them question. The architect plays only the role of provocateur, claiming innocence.

Then, there is the light, the lights of the dawn and the dusk. There are views into the light, reflections, the play of materials that capture, that imprints the colors of the sky on the skin of the building. Within the gleaming echo's or fading away, the hours slip across the green of the trees, the colors often made vivid by the interiors and the lights of the life contained by the opera, multiple and varied lights linked to the ambiance of different places, of different hours-glowing, evidently, as soon as the night arrives. Here is what guides an architect whose mission it is to provoke the unthinkable. Here is what will be felt, like a spectacle to be discovered, like sensations to be searched out. Afterwards, what remains is not the least: the interior. The interiors, the successive discoveries, the impacts of the light and the shadows through the geometry, which is the essence of grand Arab architecture. There is, seen from the interior, the discovery of the skylines of Dubai. There is the memory of creations in a place that will welcome prestigious guests who, here, will create works that will make a tour of the earth. There are encounters with music, with theatre, with the arts and their principal actors. All this to link the imagination of Dubai to Islamic culture and its pleasures.

\section{Analysis}

Places should always be true to themselves, they should never pretend to be otherwise. They should be authentic. Authentic places provide an authentic experience. By this I mean that they operate in line with their stated purpose and functions and do not pretend to be what they are not. They are true to their heritage and their culture, to the talents of their people and to the roles that they are best placed to perform in the world. The brand of their place describes how they operate, how they behave, how they create and provide value, how they treat their own citizens and visitors, the experiences they provide to them, the services they provide and the value they give to 
them, for example in social, education, economic and cultural provision. They are authentic also in that they have a history which is recognized rather than hidden, real rather than invented, celebrated rather than regretted and a culture which recognizably contributes to the experience of being there, whether as a resident, a worker or a visitor.

A place's reputation needs to be built on qualities which are positively memorable, attractive, unique, sustainable and relevant and value-adding to many different people in the place and outside of it. A place brand strategy requires a realistic, competitive and very compelling strategic vision for a city, region, or country, and needs to ensure that it is supported, reinforced and enriched by every act of leadership, investment and communication between that place and the rest of the world. However, unless every government department or local agency, local people and local companies, consistently act in line with the brand strategy and communicates and demonstrates the same carefully developed brand, people in other places will quickly become confused about what the place brand stands for, its purpose.

The purpose of a place is what it is specifically known for, often what it specializes in or what it does best, often for the particular skills or knowledge of its workforce, for its culture or its heritage, or some clearly identifiable and easily comprehensible mix of these. For example Detroit is known for making automobiles, Seattle for software design and the manufacture of aircraft, Las Vegas is known for gambling and entertainment, the City of London for financial trading, Sophia Antipolis in the south of France for new technology, research and development and Bayreuth in Germany for its celebration of culture. But here Dubai is known for what? A fluctuating identity lost between different norms. Sometimes as a new Wall Street, other as the Middle East Hub or transit.

Creating an opera house in Dubai is a movement to put Dubai on the class cities map. The superficial manner of dealing with the city and people tends to drive the culture away back to the desert, to the sand where natives belong and now there are retreating back to it. Or is a trend to make the city fulfilling the cultural requirements for the cultural city of the Middle East which has been for a long time moving between Cairo and Syria.

So, a cultural place brand is an expression of how a place currently operates and behaves or, more often, of its desired future reality, often expressed in a visionary but realistic strategy for its future purpose, the key development actions to achieve the vision, and effective and memorable communications that record progress on the strategy for target audiences. Having a common and agreed purpose enables people to talk about the place, to explain what it stands for. And over time this explanation and message becomes a self-fulfilling prophecy as it is virally marketed by its citizens, employers, governments and its visitors. Figure 6 shows the analysis of each case from the perspective of: Culture, City and Branding of both case studies.

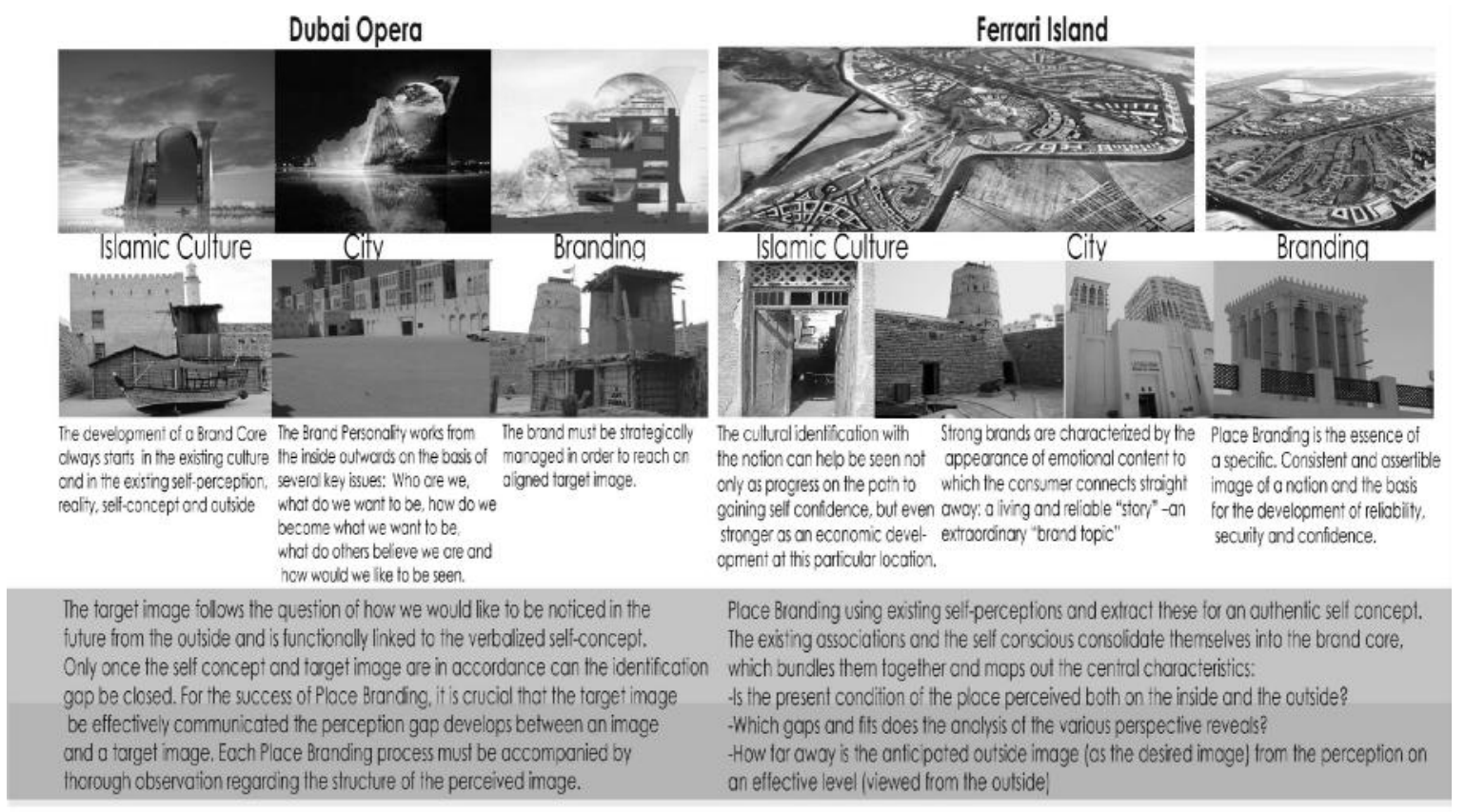

Figure 6. The analysis of both case studies Islamic Culture, City and Branding Branding the City through Culture 


\section{Analytical Review}

Culture branding is a result of a merge between three distinct trends (Figure 7). On the one side is the aspect of place management. Due to the significant success and effectiveness of product branding in the commercial sector and especially due to the advent and increasing application of corporate branding (which is conceptually similar to city branding), branding is adopted increasingly in cities. Particularly destination branding is a common endeavor all over the world with theoretical and practical suggestions that have been accumulated into a significant body of knowledge. Crucial for city branding are two elements that connect it to culture. The first is the importance of the image of the city for city branding and its power to influence even the shaping of the city itself. The second is the heavy dependence of the city's brand on the city's identity ${ }^{22}$.

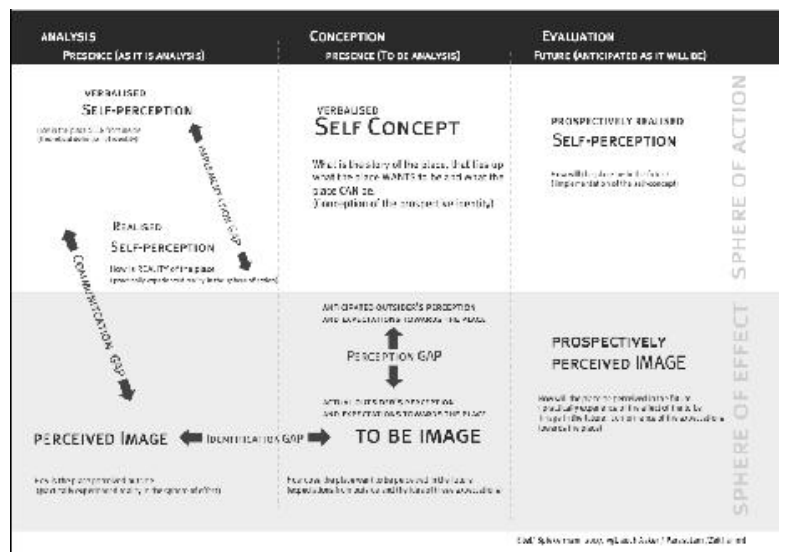

Figure 7. Place Brand Identity Model Eitel/Spiekermann

Attempting to bring the issue of city branding through the use of Islamic culture on a more practical level, it is useful to assess the significant elements of such branding. Branding is a notion developed and used in marketing, so its main and vital element is customer or user orientation. It is also vital, then, to understand what the city users appreciate in a city and particularly in a city that is branded as a center of culture and entertainment. Arguably treating the city as a brand that provokes an association with culture/entertainment means that we are choosing as targets a group of people that value highly this kind of associations ${ }^{23}$.

Florida ${ }^{24}$ discusses one type of such people, what he terms creative people and what they value in a city. He suggests that the physical attractions that most cities focus on building - sport stadiums, freeways, urban malls and tourism and entertainment districts that resemble theme parks - are irrelevant, insufficient or actually unattractive to many creative class people. What they look for in communities are abundant high-quality amenities and experiences, an openness to diversity of all kinds, and above all else the opportunity to validate their identities as creative people. Their settings, they need to work on building the necessary infrastructure. Evans provides a valuable and insightful analysis of what he terms the cultural production chain. As he explains, in order to translate the definitions of cultural industry activity and production, and to provide a conceptual framework for arts and cultural planning and the determination of an arts infrastructure, a production chain analysis has been applied to culture. This attempts to divide cultural economic activities between five interrelated stages and requires an assessment of a city or location's capacity to sustain and distribute cultural activity and products through its infrastructure.

As mentioned in "Branding your City" CEOs for Cities report, (Figure 8 \& 9) if your city wants to initiate a brand strategy, the following questions have to be answered honestly and completely:

- What does the place stand for today - both its strengths and weaknesses?

- What can and should the place stand for in the future, and how do we articulate that?

- What will make the place unique, valued and attractive to target businesses and consumer audiences?

- How will we make this new positioning a reality?

- What role do key stakeholders and community groups have in bringing the brand to life?

- How will we measure success of the brand strategy?

Here we will concentrate on step 4 as the aspirational identity for the place is the important coefficient related to Culture. And we have to identify the following questions:

- What do you want the place to stand for?

- What associations do you want people to think of when they think of the place?

- What is the ideal personality or persona for the place?

- What type of experience would you like to have there?

An aspirational brand identity consists of the associations you want people in the future to make when they think of your community. It is how you want target audiences to view the brand and the benefits they expect to receive from it. It should influence future business and community decisions. It is important for the aspirational identity to be within reach and credible for the brand. Additionally, it should also be an identity that the place can sustain for a long period of time. Think of this as the North Star, something the place should always strive to achieve. Understanding the gap between the current image and the aspirational brand identity will influence the evolution of the positioning. 


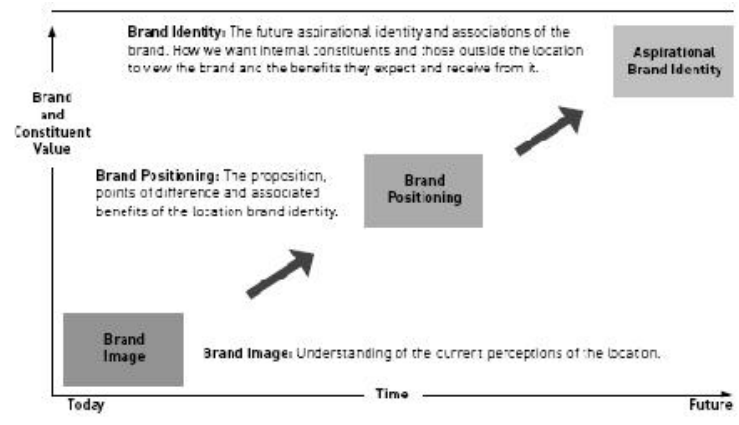

Figure 8. The Eight Steps Process to Develop a Place Brand

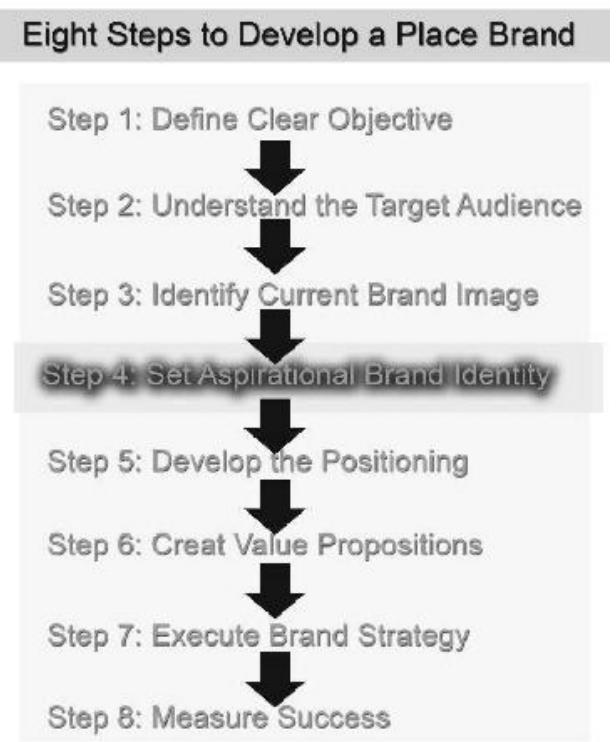

Figure 9. Moving from Brand Image to Brand Identity

\section{Conclusion}

As already mentioned above, apart from arts and culture, the other element that can provide local distinction in the globalized world is the landscape ${ }^{25}$. As Hubbard ${ }^{26}$ describes, "although the entrepreneurial city is perhaps best considered a 'virtual' city, one constituted through a quixotic range of images and representations (so much that it no longer makes sense to distinguish between the myth and reality of the city), it is probably the urban landscape itself that sends out the most important messages about the nature of place. As such, the physical spaces of the city can be considered as belonging to the same set of cultural forms as brochures, videos, guidebooks or advertisements.

A final but very important consideration is the effect of culture/entertainment branding and generally branding on the social mosaic of cities. As Mommas suggests, “...economic functionality alone does not explain the attraction and popularity of city branding. Its socio-cultural effect is also important. Brands derive their attraction largely from the fact that they introduce a certain order or coherence to the multiform reality around us. Brands enable us to more easily 'read' each other and our environment of places and products. In this respect ${ }^{27}$.

Branding is not simply an economic activity, inspired by market considerations. In a deeper, cultural sociology sense, it is above all a manner of introducing order and certainty into what is in principle a chaotic reality". For exactly this reason it is necessary to involve in the city branding process the local population and make an effort to really support local creativity and not only 'force' on the city and its residents culture imported from the outside.

Branding is a strategic response to the problem of defining particularity in an increasing standardized and even trivialized world ${ }^{28}$. As Kunzmann ${ }^{29}$ concludes, certainly regional and city marketing and branding has to promote cultural development. And, at the same time, cultural development and the management of the leisure and entertainment offering of cities has to reinforce the city's brand in a coordinated and harmonious manner.

\section{Reference}

1 M. Kavaratzis \& Ashworth GJ. 2005. City Branding: An Effective Assertion of Identity or a Transitory Marketing Trick? Tijdschrift Voor Economische en Sociale Geografie, forthcoming.

2 M. Barke. 1999. City Marketing as a Planning Tool, In Pacione M (ed). Applied Geography: Principles and Practice. London: Routledge

3 GJ. Ashworth GJ \& Voogd H. 1994. "Marketing and Place Promotion". In Gold JR and Ward SV (eds), Place Promotion: The Use of Publicity and Marketing to Sell Towns and Regions. Chichester: John Wiley and Sons Ltd.

4 M. Barke. 1999. City Marketing as a Planning Tool, in Pacione $M$ (ed.). Applied Geography: Principles and Practice. London: Routledge. pp. 486

5 T. Hauben, M. Vermeulen \& V. Patteeuw. 2002. City Branding: Image Building and Building Images. Rotterdam: NAI Uitgevers.

SK. Rainisto. 2003. Success Factors of Place Marketing: A Study of Place Marketing Practices in Northern Europe and the United States. Doctoral Dissertation, Helsinki University of Technology, Institute of Strategy and International Business.

M. Trueman, M. Klemm \& A. Giroud. 2004. "Can a City Communicate? Bradford as a Corpo-rate Brand". Corporate Communications: An International Journal. Vol. 9 No. 4 pp. 317-330

6 M. Kavaratzis \& Ashworth GJ. 2005. City Branding: An Effective Assertion of Identity or 
a Transitory Marketing Trick? Tijdschrift Voor Economische en Sociale Geografie, forthcoming.

7 P. Kotler \& D. Gertner. 2002. "Country as Brand, Product and Beyond: A Place Marketing and Brand Management Perspective”. Journal of Brand Management. Vol. 9 No. 4-5 pp. 249261

N. Papadopoulos \& L. Heslop. 2002. "Country Equity and Country Branding: Problems and Prospects". Journal of Brand Management. Vol. 9 Issue $4 / 5$ pp. 294-315

8 S. Anholt. 2002. "Nation Branding: A Continuing Theme". Journal of Brand Management. Vol. 10 No. 1 pp. $59-60$

F. Gilmore. 2001. A Country - Can It Be Repositioned? Spain - the Success Story of Country Branding, Brand Management. Vol. 9 No. 4-5 pp. 281-293

9 J. O'Shaughnessy \& N.J. O'Shaughnessy NJ. 2000. "Treating the Nation As a Brand: Some Neglected Issues". Journal of Macro-marketing. Vol. 20 No. 1 pp. 56-64

10 I. Endzina \& L. Luneva. 2004. "Development of a National Branding Strategy: The Case of Latvia". Place Branding. Vol. 1, No. 1, pp. 94-105. F. Gilmore. 2001. A Country - Can It Be Repositioned? Spain - the Success Story of Country Branding, Brand Management. Vol. 9 No. 4-5 pp. 281-293

11 N. Morgan, A. Pritchard \& R. Pride (eds.). 2002. Destination Branding: Creating the Unique Destination Proposition. Oxford: ButterworthHeinemann

12 G. Hankinson. 2001. "Location Branding: A Study of the Branding Practices of 12 English Cities". Journal of Brand Management. Vol. 9 No. 2 pp. $127-142$

G. Hankinson. 2004. "Relational Network Brands: Towards a Conceptual Model Of Place Brands". Journal of Vacation Marketing. Vol. 10 No. 2 pp. 109-121

13 G. Hankinson. 2004. "Relational Network Brands: Towards a Conceptual Model Of Place Brands". Journal of Vacation Marketing. Vol. 10 No. 2 pp. 109-121

14 M. Kavaratzis \& Ashworth GJ. 2005. City Branding: An Effective Assertion of Identity or a Transitory Marketing Trick? Tijdschrift Voor Economische en Sociale Geografie, forthcoming

15 G. Evans. 2003. "Hard Branding the Cultural City: From Prado to Prada". International Journal of Urban and Regional Research. Vol. 27 No. 2 pp. 417-440

J. Hannigan. 2003. "Symposium on Branding, the Entertainment Economy and Urban Place Building: Introduction". International Journal of Urban and Regional Research. Vol. 27 No. 2 pp. $352-360$
16 G. Evans. 2001. Cultural Planning: An Urban Renaissance? London: Routledge

17 B. Florian B. 2002. "The City As A Brand: Orchestrating A Unique Experience". In Hauben T, Vermeulen M \& Patteeuw V. City Branding: Image Building and Building Images. Rotterdam: NAI Uitgevers

18 M. Kavaratzis \& Ashworth GJ. 2005. City Branding: An Effective Assertion of Identity or a Transitory Marketing Trick? Tijdschrift Voor Economische en Sociale Geografie, forthcoming

19 Joseph Rykwert. 2000. The Seduction of Place The History and Future of the City. Oxford: Oxford University Press

20 S. Anholt. 2003. "Branding Places and Nations". Chapter 14. Brands and Branding. London: The Economist

21 S. Anholt. 2002. "Nation Branding: A Continuing Theme". Journal of Brand Management. Vol. 10 No. 1 pp. $59-60$

22 M. Kavaratzis \& Ashworth GJ. 2005. City Branding: An Effective Assertion of Identity or a Transitory Marketing Trick? Tijdschrift Voor Economische en Sociale Geografie, forthcoming

23 M. Kavaratzis \& Ashworth GJ. 2005. City Branding: An Effective Assertion of Identity or a Transitory Marketing Trick? Tijdschrift Voor Economische en Sociale Geografie, forthcoming

24 B. Florian. 2002. "The City As A Brand: Orchestrating A Unique Experience". In Hauben T, Vermeulen M \& Patteeuw V. City Branding: Image Building and Building Images. Rotterdam: NAI Uitgevers

25 K.R. Kunzmann. 2004. "Culture, Creativity and Spatial Planning”. Town Planning Review. Vol. 75 No. 4 pp. 383- 404

26 P. Hubbard. 1998. Introduction to Part 3, in The Entrepreneurial City: Geographies of Politics, Regime and Representation. Chichester: John Wiley \& Sons Ltd.

27 M. Kavaratzis \& Ashworth GJ. 2005. City Branding: An Effective Assertion of Identity or a Transitory Marketing Trick? Tijdschrift Voor Economische en Sociale Geografie, forthcoming

28 S. Zukin. 2002. "Re-imaging Downtown: Problems of Branding the Particular, in Danish Ministry of the Environment, European Cities in a Global Era". Follow-up Report to the Conference. Copenhagen: 14-15 November 2002.

S. Zukin. 2004. "Dialogue on Urban Cultures: Globalization and Culture in an Urbanizing World". UN Habitat World Urban Forum. Barcelona: 13-17 September 2004

29 K.R. Kunzmann. 2004. "Culture, Creativity and Spatial Planning". Town Planning Review. Vol. 75, No. 4, pp. 383- 404 